\title{
THE ORIGIN AND RELATIONSHIP OF THE LARGE MAMMALS OF NORTH AMERICA
}

\author{
BY \\ MADISON GRANT
}



grith

Compliments of the Author. 

THE ORIGIN AND RELATIONSHIP OF THE LARGE MAMMALS ÓF NORTH AMERICA 
i 
THE ORIGIN AND RELATIONSHIP OF THE LARGE MAMMALS OF NORTH AMERICA

BY

\author{
MADISON GRANT
}

SECRETARY OF THE NEW YORK ZOOLOGICAL SOCIETY

REPRINTED FROM THE EIGHTH ANNUAL REPORT OF THE

\title{
fRew 具ork \%oologícal Society
}

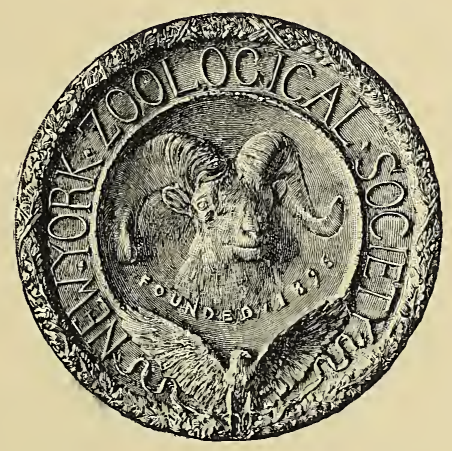

NEW YORK

OFFICE OF THE SOCIETY, 11 WALL STREET 1904 
COPYRIGHTED, I904, BY

THE NEW YORK ZOOLOGICAL SOCIETY

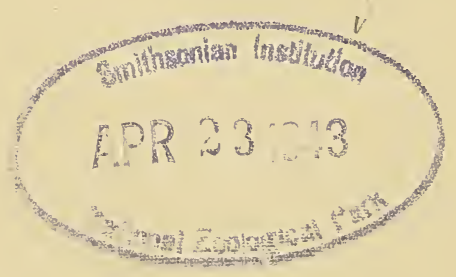

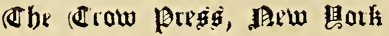




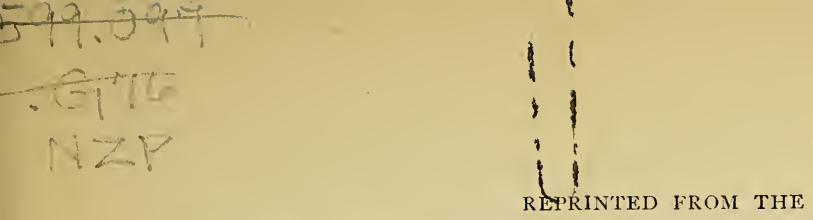

Eigbth Annual Report of the Rew 圌ork \%oological Socicto.

\title{
THE ORIGIN AND RELATIONSHIP OF THE LARGE MAMMALS OF NORTH AMERICA
}

\author{
BY MADISON GRANT \\ SECRETARY OF THE NEW YORK ZOOLOGICAL SOCIETY
}

The increase of knowledge of the true relationship of mammals, and their geographical distribution, has now reached a point where it is possible to analyze the mammalian fauna of North America, and to indicate the continent where the original expansion and radiation of the various groups took place. Paleontology has, of recent years, shed a flood of light upon this subject, and offers, in many instances, definite proof of what has heretofore been largely conjecture.

It is the purpose of this article to briefly review the living large mammals of the United States and Canada, and to endeavor to trace their past history.

The higher fauna of North America, when compared with that of other large continents, presents an astonishing poverty, as to the number both of genera and of species, and the latter are, in the great majority of cases, very closely allied to Old World forms.

The animals which the first settlers found along the Atlantic coast seemed almost identical with those they had left behind in England or on the adjoining continent. This resemblance was very close in the North, but in the South a larger number of unfamiliar forms were found. As the seventeenth and eighteenth centuries were not ages of scientific accuracy in matters zoological, names were applied at random, just as was done by the Dutch settlers in South Africa, with the result that many a misfit occurred, and the same animal bore distinct names in different sections of the country. 
Along with this close resemblance, there seemed at first to be also an appreciable inferiority in the size and beauty of the animals found in America, as compared with their Old World congeners. The puma and the jaguar were compared with the lion and tiger, somewhat to the discredit of the former, and our black bear, which was surprisingly numerous in Colonial times, suffered also, when compared with the brown bear of Europe; as did our Virginia deer, in comparison with the European red deer.

Later, however, when the frontier was pushed inland, and the grizzly, the wapiti and the moose were measured by the standards of the European brown bear, red deer and elk, no such superiority could be claimed for the Old World animals. In profusion of distinct types, however, North America, with its bison and prong-horn, which, with the black-tailed deer and the wapiti, virtually monopolized the great prairies and plains of the West, could not vie with the magnificently diversified fauna of Africa, with its hundred and more species of bovine antelopes, to say nothing of other huge mammals.

Close as is the relationship of Eurasian and North American mammals, it never amounts to specific identity in the view of the best American systematists, who differ in this respect from European zoologists. ${ }^{-}$The polar bear, and one or two smaller arctic mammals form the sole exceptions to the above statement.

\section{FIRST RADIATION.}

This poverty of animal life, both as to variety and number, has not always existed, and a close study of the fossil mammals of North America, of which we have a very complete record from the Rocky Mountain region, demonstrates that there have been two separate and distinct periods of great development and radiation of mammals on this continent, together with several clearly distinguishable immigrations from other lands. The last of these immigrations from the Old World, by way of Behring Straits, gave us the predominant members of our present fauna.

The first of these periods of development is known as the Puerco, and dates from the very dawn of the Basal Eocene, some three million years ago. Deposits of this horizon are found in New Mexico, and have revealed to us a large and varied fauna, with true mammals, some as large as a Newfoundland dog. In European beds of a corresponding age, the Cernaysien, a similar but more limited fauna is found.

This Puerco fauna flourished and radiated, paralleling many 
of the existing orders of mammals, and giving rise to primitive Carnivores, known as Creodonts, primitive Ungulates, known as Amblypoda and Condylarthra, and still other orders not so easily defined. Only partial traces of types which were ancestral to the Puerco fauna are found in the underlying Laramie beds, which are assigned to the top of the Cretaceous period. This would probably indicate that the Puerco mammals, to a large extent, come in from some other country, probably from the North.

\section{SECOND RADIATION.}

By the Middle Eocene, the early and generalized types of this Puerco fauna were rapidly dying out, leaving only a few carnivorous forms to linger on into the Oligocene. We do not, of course, know the causes of their disappearance, but it is safe to hazard the conjecture that their structural development, especially their limited brain capacity, was inadequate to cope with that of the new and more highly organized animals which suddenly appear in the Lower Eocene. These new types were possibly descended from some side line of the earlier radiation, and were derived from members of the Puerco group, which had lingered on in the original northern home, but no direct lines connecting these two faunæ are known.

Assuming that the Puerco mammals were driven out of more northerly or boreal lands, where they had originally developed, by a declining temperature, it is conceivable that some animals remained behind and adjusted themselves to the changed conditions, until a still further increase of cold forced them also to follow the path of their predecessors, southward.

Some of these Lower Eocene types of this second radiation, which are found in the Wasatch beds of Wyoming, have sent down lines of descendants, which have ultimately culminated in existing animals. At this time first appear the horses, tapirs, rhinoceroses, camels and dogs. Some of these animals, such as the horses and rhinoceroses, are found contemporaneously in Europe; others, like the camels, are peculiar to this country.

Being more highly organized and better adapted to their environment, these new types entirely supplanted the older fauna, and by the Oligocene, this transformation was complete, and the older fauna had disappeared. This Wasatch fauna culminated in the Miocene, and then faded gradually away on this continent, until in the Middle Pleistocene they were largely supplanted by new arrivals from Eurasia. 
Similar radiations, on as large a scale, have taken place in early Eocene times among the marsupials in Australia, and somewhat later, in South America, which was then, and long afterwards, separated from North America, although probably for a shorter period connected with Africa and Australia, by way of Antarctica. In Australia the rapid replacement of the native Marsupials by the better equipped placental mammals, when the latter were introduced by man, is analogous to the manner in which the Puerco fauna was supplanted by the Wasatch fauna, through inability to successfully compete with those more highly organized types.

\section{DECLINE OF ANCIENT GROUPS.}

After attaining a high degree of development this second or Wasatch fauna also declined, and one of the causes which contributed to its disappearance was the gradual elevation of the Western half of North America and the draining of the ancient lake basins there, with consequent loss of moisture.

Desert lands, however, are not necessarily unfavorable to the development of structural variety and great bulk in animals. On the contrary, arid conditions seem to favor the development of large-hoofed animals, by imposing upon them the necessity of traveling over great stretches of country to find water during a drought. South Africa is a country of open plains, scantily supplied with water, many large areas being quite desert, and yet no other region of the earth can show such profusion of large mammals.

As speed and endurance are to some extent correlated with bulk, no animal of small size could long survive competition with the faster and more enduring members of its own or a rival race. Increased size leads to an accelerated development, until a limit is imposed by the question of food supply. The larger the animal the more food it requires in proportion to its bulk, hence the larger animals must spend most of their time feeding, and if, through climatic changes, food becomes scarce, or enemies appear which they cannot resist, the larger animals are the first to succumb.

A race, therefore, tends to increase in size until a maximum is reached, and is then apt to become suddenly extinct. The rhinoceroses, elephants and horses are now on the verge of extinction, all their smaller relatives having been weeded out by competition. 


\section{AFRICAN FAUNA.}

In this connection, the origin of the South African animals may be briefly referred to. Madagascar has a peculiar fauna resulting from long isolation, but the ancestral types came from Africa, where, in later times, most of these particular animals have died out.

It had long been supposed that the lemurs, the pangolins, the aardvarks, and some other types, were the only remnants of this original fauna, and that the typical large mammals of Africa originated in Eurasia, and were driven south into Africa by the advance of the glaciers in comparatively recent times. Recent investigations, however, have demonstrated the fallacy of this view, and at present the best authorities concur in viewing Africa, south of the Sahara, or the Ethiopian region, as having experienced a radiation of large mammals, quite peculiar to itself, but which took place after the separation of Madagascar.*

That the elephants originated in Africa has been demonstrated by the recent discovery in Egypt of fossil forms, clearly ancestral to the modern Probosicidians. The Sirenia, the hyrax, the hippopotamus, and related swine, the giraffe, and the wonderful group of bovine antelopes in all probability attained their development in. Africa, and, possibly all of the Bovidae originated there also. In Pliocene and Lower Pleistocene times many of these forms pushed north, in some cases as far as England, there becoming extinct or retreating into Africa again upon the advance of the glaciers, but leaving behind in Europe and Asia, some of their members, which successfully adjusted themselves to temperate or subarctic conditions.

\section{PREGLACIAL FAUNA OF AMERICA.}

During these same periods before the approach of the glaciers a magnificent fauna flourished in North America, consisting of camels, horses, ground sloths, elephants, mastodons, sabretoothed tigers, and others, including distinct forest and plains faunae, but few of these animals seem to have survived the great glaciers. One of the survivors was the mastodon, which, origi-

* This hypothesis was first fully set forth by Prof. Henry Fairfield Osborn, before the New York Academy of Science in I9O0, and has been more than confirmed by the explorations of the Egyptian Geological Survey, published by Andrews \& Beadnell. 
nating in Africa, spread over the world, and even reached the southern end of South America in Pliocene times.

Other animals of this early period have probably survived, but we are without such knowledge of the forest fauna of pre-glacial and post-glacial times as would enable us to trace them down to existing forms. Our American deer, Odocoileus, the pronghorn, peccaries and raccoons, probably are survivors of this same fauna. But the fact remains that the great majority of the early American mammals perished, probably because of their inability to cross the Mexican deserts, and because of the destruction of their normal food supply.

\section{EURASIATIC CONNECTION.}

During and after the glaciers came a new fauna, the immediate ancestors of the predominating types of to-day. At intervals throughout Tertiary times there apparently existed a broad land connection with Eurasia, over the present site of Behring Sea. This connection probably existed in the Lower Eocene, Lower Oligocene, Middle Miocene, Upper Pliocene, and Lower Pleistocene, and was interrupted in Middle and Upper Eocene, Upper Oligocene and Lower Miocene times.

We have several corresponding invasions from Eurasia. The first of these invasions was in the Lower Eocene; the second in the Lower Oligocene; the third, bringing in the Proboscidians, in the Miocene; the fourth occurred during the Lower and Middle Pleistocene, bringing the ancestors of most of the typical American animals of to-day.

This Eurasian land connection had a sufficiently temperate climate during early Tertiary times to admit of the interchange of animals which required either an unbroken forest or a temperate climate, and consequently the faunae of the eastern and western continents were very closely related, but as time went on they became more distinct, until it is evident that some obstacle existed, probably the increasing cold temperature of the evernarrowing land bridge. Animals which could sustain great cold and long journeys still crossed, but the more southern types were cut off.

THE BOREAL THEORY.

In this connection it is necessary to mention the recently advanced theory of the boreal origin of mammals, indeed of all life, both animal and vegetable. The chief evidence, so far as it 
relates to mammals, adduced by the advocates of this theory, lies in the singular and simultaneous appearance in Europe and in America, of the same types of animals, the hypothesis being that these animals came from a common boreal home.

As will appear below in the detailed consideration of our various animals, the place of origin of each group, based on positive and not on negative evidence, can be found in practically all cases. There can be no serious doubt, for instance, that the bear originated and developed in Eurasia. The same is true of the cats comprising the type genus Felis, and of the great deer genus Cervus.

In fact the only American animals about the origin of which there is much doubt, are the moose and the caribou. These two undoubtedly originated and attained their development in some far northern land. It is not necessary, however, to assume a polar continent for these two genera, as the existing land areas to the north of the American continent, or that portion of Siberia lying within the Arctic Circle with the recently submerged and adjacent coast, would supply boreal land areas quite sufficient in extent for the development of these types.

\section{TYPE DIVERGENCE.}

In carefully considering the various types of North American mammals a very important clew to their origin can be found in the degree of differentiation which each one of these animals has achieved. It would appear that this degree of radiation and of departure in structure from their Old World kindred, would, in some measure correspond to the amount of time which has elapsed since the first appearance of these animals in North America. The deductions in this article are based on these lines of reasoning, and the conclusions are in most instances confirmed by the fossil record.

When we find, as in the case of the genus Cervus, of which our sole American representative is the wapiti, that the Old World has about twenty species belonging to this genus and to closely allied genera; that is, one species as an inhabitant of the New World, against about twenty in the Old World, (and some of these Old World species, like the Altai wapiti from Mongolia, are very closely akin to the American wapiti); when we can go from England eastward through Germany, Hungary, the Caucasus and the mountains of Central Asia, and find the red deer growing larger and finer, and fading imperceptibly through one 
species after another into this Altai deer, which is in turn almost indistinguishable from our great American wapiti, how can we escape the conclusion that the centre of radiation of the genus Cervus was in Eurasia, and our wapiti so recent an immigrant from the Old World that it has not had the time to evolve, under the varied influences of its new habitat, well marked species, there being at most only two or three races of subspecific value.

Turning to the fossil record we find that no member of this genus has been found in America of an earlier age than the Middle Pleistocene.

A similar line of reasoning applied in turn to each of the large American animals, enables us to draw what appear to be accurate conclusions, not only as to their original home, but as to the relative duration of the type in America.

Not all our animals, however, came from the Old World, although the predominating types undoubtedly did. South America contributed a few types, and others, like the raccoon, peccary, prong-horn and American deer, are either autocthonous, or else have been here so long that their specialization has taken place entirely on this continent.

To take up the possible places of origin of our living mammals in the inverse order of their importance, we find them to be: a migration by a possible land bridge over the Atlantic; migration from South America; development in North America, and last, and by far the most important, migration from Eurasia by way of Behring Sea.

ATLANTIC BRIDGE.

A mid-Atlantic land connection has been suggested, but has little evidence in its favor, and can be practically disregarded, and, while there is no doubt that continuous land connected Greenland, Spitzbergen and Scandinavia in Pleistocene times, no known element of our fauna was derived from this source.

\section{SOUTH AMERICA.}

South America was entirely separated from North America until the Pliocene, but apparently since that period, has been more or less continuously united to North America. The southern continent, during this long period of isolation, before the Pliocene, developed several groups of large and clumsy animals which almost defy classification, but which stand close to the Ungulates, 
and for the reception of which several new orders have been created.

During the Lower Pliocene the mastodons entered South America, and the Edentates, represented by the extinct ground sloths and the living armadillos, found their way into North America, together with a number of hystricomorph, or porcupine-like Rodents, which have since spread throughout the world.

In the Upper Pliocene a more extensive interchange of animals took place, South America receiving from the North its camellike llamas, its cats, its dogs, its raccoons, its numerous deer, and many others. The peccaries did not reach South America until the Pleistocene.

The cats, represented by the sabre-toothed tigers, entering the southern continent at this time (Upper Pliocene) very possibly played a large part in the destruction of the giant herbivores, which flourished at that time on the Pampas. It would almost seem that the sabre-toothed tigers were modified in their marvellous dentition for the express purpose of preying on these huge and thick-skinned animals.

South America, at this time, received its deer, all of which are closely related to Odocoileus, but which have been there long: enough to evolve nearly twenty distinct species.

The horses, too, entered South America during this period, and survived there nearly until the arrival of Europeans.

Of the animals which North America received from the southern continent during the Pliocene, few have seemingly survived, except the porcupines and armadillos. The opossum did not come from South America, but is a survivor of a family of early Marsupials, Didelphidae, which were once widely spread throughout the northern hemisphere, but which have become extinct in the Old World.

\section{NORTH AMERICA.}

We have, in America, one family of the Carnivores, Procyonidae, and two distinct families of hoofed animals, Dicotylidae and Antilocapridae, and one very important genus of the deer family, Odocoileus, none of which have close relatives in the Old World. All these four groups are probably of autocthonous origin, and their peculiar characters are described at length below.

\section{EURASIA.}

The remaining large North American mammals, the wapiti, the bison, the musk-ox, the mountain sheep, the mountain goat, 
many cats, including the lynxes, the bears, the otter, the wolverine, the fisher, the marten, the mink and the beaver are all more or less recent immigrants from Eurasia. The moose and caribou also probably came from the extreme north of the same continent.

It is from the character of the animals above named, which are nearly all of northern or subarctic habit, that we draw the inference that this land connection between the continents lay far to the north. From their close relationship to Eurasian animals we can also infer that the connection persisted until very recent times. Let us now examine the chief groups of the large American mammals one by one, and see what knowledge can be gained from a study of the distribution of the members of each genus, and of closely allied genera.

\section{CARNIVORES.}

BEARS.

Taking up the Ursidae first of all, we find that all of the American bears belong to the type genus Ursus, although there are several ill-defined subgenera.

Like the deer, the bears are essentially northern animals, and are widely distributed throughout Eurasia, with a single outlying species in North Africa. Their absence from the Ethiopian region, or Africa south of the Sahara, is probably due to their inability to pass the barrier of the deserts.

If we take the common European brown bear, U. arctos, and follow; by way of the great mountain ranges, its gradually increasing racial variations across Europe and Asiatic Russia, we find one type fading into another, until in the hairy-eared bear of Amurland, U. piscator, and the great Kamchatkan fish bear, $U$. behringiana, on the easternmost confines of the Old World, we have bears very close in type and structure to the brown bears of Alaska on the American side of the straits. The similarity would probably prove even more striking than we now believe, if we had more accurate data about this great fish bear, which, until the discovery of the Kodiak bear, was the largest known carnivore.

Neither of these bears is inferior in size to the Pleistocene cave bear, U. spelaeus, or its American congener, Arctotherium.

More distantly related to these Eurasian bears are the grizzlies, and most distant of all are the black bears. Leaving out of con- 
sideration the white bear, which is circumpolar in its distribution, and is assigned to a separate subgenus, Thalarctos, we can place all the American bears in one of these three groups.

\section{THE BLACK BEAR GROUP.}

Judging from the degree of type divergence and from distribution, the first of these bears to arrive in North America was the black bear group, $U$. americanus. Its variation from the true Ursus is of sub-generic value, and the members of the group are assigned to the subgenus Euarctos. This group we find distributed throughout the length and breadth of North America to the limit of tree growth in the North and West, with a subspecies, $U$. sornborgeri, in Labrador, and species in Florida, U. floridanus, in Louisiana, $U$. luteolus, a recently described bear of large size from Queen Charlotte Island, U. carlottae, and most distinct of all, the blue or glacier bear, U. emmonsi, with a limited distribution in Alaska, in the district of the St. Elias Alps, and eastward among the rugged coast ranges as far as Juneau.

In South America a closely related form, the spectacled bear, $U$. ornatus, has followed the Peruvian Andes south of the Equator. It is sometimes assigned to a subgenus, Termarctos, but is very closely related to the typical black bear, $U$. americanus.

As the black bear only extends into Mexico there is a long break in the distribution of the genus, where bears have apparently died out. So that we need not be surprised to find that this isolated South American form is somewhat aberrant. This bear is, furthermore, the sole representative of the family in the southern hemisphere.

It is quite evident from the distribution of the group that its residence in America is of considerable antiquity.

\section{THE GRIZZLY GROUP.}

All these black bears differ from the European bears more than do the grizzlies. From this fact and from the distribution of the grizzlies along the range of the Rockies, we can safely believe that they are later arrivals from Eurasia than are the black bears.

The grizzlies have not evolved any well-marked species except perhaps the Barren Ground grizzly of the far North, $U$. richardsoni, about which very little is known. 
The type species, $U$. horribilis, is distributed throughout the Rockies from Alaska to Mexico, with two subspecies, the Alaskan grizzly, U. alascensis, described from Norton Sound, the existence of which is still in dispute, and the great California grizzly, U. horriaeus.

THE BROWN BEAR GROUP.

The third, and judged by the same tests, the latest group to arrive was that of the Alaskan brown bears. Its members have departed but little from the Eurasian bears, and a comparison of forms may bring the resemblance still closer.

These bears have known a distribution along the South Alaska coast as far as the mountains at the head of Portland Canal, and extend probably far inland toward the north. While the group has split up into a number of races, the gradations are scarcely distinguishable and it is probable that the further examination of specimens from intermediate points will result in the merging of some of the species.

The American type of the brown bear is the great Kodiak bear, $U$. middendorff, from Kodiak and adjoining islands. It is the largest of all living carnivores, and is closely related to the mainland bear along the adjoining coast.

These mainland bears have been assigned to a number of species or subspecies, beginning on the west in the Alaskan peninsula: $U$. merriami or $U$. gyas; further to the east, $U$. kidderi of Cook Inlet; $U$. dalli of Yakutat Bay, and $U$. sitkensis, which appears to be the most eastern of the group.

Turning now to the fossil record we find no fossil bear in North America until the Pleistocene, whereas bear abounded in Europe in the Lower Pliocene. A related form, known as Arctotherium, entered South America during the Pleistocene, but undoubtedly came from the north, as it has also been found in the Pleistocene cave deposits of California.

\section{MUSTELINES OR WEASELS.}

Of the American members of the Mustelidae there are but three genera which are peculiar to America. First, the American badger, Taxidea, which dates back at least as far as the Pleistocene; and the skunks, Mephitis and Spilogale, neither of which have Eurasian equivalents, nor American ancestors. Paleontology gives us but little light on these three genera. 
The Family $\bar{M}$ ustelidae is cosmopolitan from the Middle Eocene, and, as its members have always been numerous in America, we should expect to find other equally distinct forms here, but, as a matter of fact, we are indebted to Eurasia for most of the well-known forms, the otter, the wolverine, the fisher, the marten, the mink and the weasel.

\section{RACCOONS.}

The Old World family of civets, Viverridae, is entirely unknown in America, and its place is taken, on this continent, by the peculiar family of the raccoons, Procyonidae, which are of North American extraction, and have no relatives in the Old World.* The line of ancestry of the raccoons leads back on this continent in a series, of which we have the most important links, to certain primitive Canidae of the Oligocene.

The Bassariscus, one of the most interesting of the raccoons, is probably an almost unaltered survivor of one of these primitive forms.

THE WOLVES AND FOXES.

The Canidae, like the Mustelidae, swarm in North America from the Oligocene down, and in fact are cosmopolitan. The evidence of the direct descent of the more typical forms is inconclusive, but the species of the Upper Miocene, in North America, are in general more nearly related to.living South American and certain Old World types than our present wolves and foxes. This is as it should be, and is another evidence of the migration of the old types southward, and their replacement in North America by later immigrants.

The Virginia gray fox, Urocyon, forms the only distinctly American genus of this family, and is possibly a survivor of the pre-glacial fauna. Our other wolves, Canis, and foxes, Vulpes, are close relatives of Eurasian forms.

THE FELINES OR CATS.

The remaining family of the Carnivores, the Felidae, is also well-nigh cosmopolitan in distribution, and the species that form

* Panda is to be referred to the bears rather than to the raccoons. 
the type genus Felis are nearly all closely related, and vary in size and color rather than in structure.

The sabre-toothed tigers were in North America in the Pliocene, and entered South America in numbers at that time. Recent discoveries indicate an American line of sabre-tooths back to the Lower Oligocene and perhaps earlier, and one genus, Smilodon, existed until comparatively recent times, even as late as the Middle Pleistocene.

The type genus, Felis, occurs doubtfully in the Upper Miocene, and certainly in the Pleistocene, but this genus undoubtedly achieved its development in Asia, and thence spread throughout the world.

To the puma is probably to be assigned a rather more recent development, as, while it ranges from Canada to Patagonia, the local races which have arisen are all of doubtful value. Closely related fossil forms, however, suggest a possible American origin of great antiquity on this continent.

In America, the genus Lynx, which is a thoroughly northern, possibly boreal, type, contains three well-marked species, L. canadensis, L. rufus, L. baileyi, the last a western form, together with ten or more subspecies. All are closely related to European forms.

RODENTS.

Of the great order of Rodents, two interesting families are confined to North America. The curious sewellel, or mountain beaver, Haplodon, is surely of American origin. It has no near relatives outside of North America, and can probably be traced back, through Lower Miocene forms, as far as the Oligocene. The Geomyidae or pouched rats are also peculiar to America. Of the true Muridae, the genus Fiber, the muskrat, goes back to the Lower Pleistocene. Since it is closely related to the voles, Arvicola, it also is probably of Eurasian origin.

As has been already mentioned, the porcupines represent a peculiar group of South American rodents, which has now attained a world-wide distribution, and is interesting as the sole contribution of South America to the fauna of Eurasia and Africa. The genus Erithizon may have been developed in North America, but the ancestral type unquestionably came from the south. 


\section{THE UNGULATES.}

The next great group to be considered is the order of Ungulates.

PECCARIES.

Like the American deer and prong-horn, the peccaries form a peculiar American family, Dicotylidae, and are the American equivalents of the Old World swine, to which they are not closely related. They entered South America in the Pleistocene, but existed in North America throughout the Pliocene, Miocene and back into the Oligocene, and their North American ancestry has been clearly traced.

\section{BOVINES.}

BISON.

The next family of the Ungulates is the Boridae, and its largest American member is the bison, Bison americamus, which is very closely related to the European bison or wisent, $B$. bonassus, now often mis-called the aurochs.

The American bison is probably a relatively recent immigrant from the Old World. It does not occur in the Lower Pleistocene Equus fauna, but comes in abundantly just above. Several other species of fossil bison go back to about the Middle Pleistocene, one, $B$. priscus, being found fossil both in Europe and in Alaska. These bison probably represent other species which arrived at the same time, rather than the ancestral stock of the living animal.

Additional proof of its recent arrival is indicated by the fact that while attaining the greatest numerical development of any American hoofed animal, and with an immense range, extending from Great Slave Lake to Mexico, from the Rockies to the Atlantic tidewater, and northeastward into New York State, it appears to have developed but one imperfectly marked subspecies in the far North, known as the wood buffalo, B. americamus athabascae.

\section{MUSK-OX.}

The bovine nearest to the bison, in point of size, is the muskox, Ovibos moschatus, which is now entirely confined to the Bar- 
ren Grounds, south and east of Cape Bathhurst, and the great Arctic islands to the north of the continent, including Greenland, where the local race has been described under the name of $O$. wardi.

For some reason probably connected with the food supply, it has disappeared from Alaska, and it is only recently extinct in the Old World. The musk-ox probably came into America about the same time as the bison, in fact all the Bovidae probably arrived about the Middle Pleistocene, at the same time as Cervus. In the recently discovered cave fauna of Arkansas a large species of musk-ox has been found.

\section{MOUNTAIN SHEEP.}

With the mountain sheep we have a case very similar to that of the bears and the wapiti. The genus Ovis ranges throughout Eurasia, and like Ursus and Cervus, has one outlying species in North Africa.

In Asia it extends eastward to Kamchatka, having, apparently, its distributional centre in the central Asiatic plateau, where it culminates in the great Marco Polo sheep, $O$. poli, whose horns have a sweeping open spiral, and which is one of the most highly prized trophies that can fall to a sportsman's rifle.

The Eurasian sheep nearest in habitat and structure to the American form is the Kamchatkan sheep, O. nivicola, and the closely related $O$. sirensis of Mongolia. The great Ovis ammon is also close. In fact, nearly all the Eurasiatic members of the genus are very closely related to each other, and to the American forms.

These latter, while obviously of Eurasian origin, have been here long enough to split up into three good species and four subspecies, chiefly characterized by their coloration, but in some cases by their horn development.

Beginning at the northwest, the Alaskan white sheep, O. dalli, ranges throughout Alaska and the adjoining Rockies. The distribution of the closely related Fannin sheep, O. fannini, which is a white sheep with dark saddle-patch and other dark markings, is much more limited, and appears to be surrounded by the distributional area of $O$. dalli. Its value as a full species remains to be determined. Both these sheep resemble the type big-horn of the Rockies in the relatively close spiral of the horns, but do not grow so large in bulk. 
To the south of these two sheep and in the Cassiar Mountains of British Columbia, thus interposed between it and the true Rocky Mountain big-horn, is the Stone sheep, O. stonei, which is very dark in color, and the horns of which have a decidedly open spiral, suggestive of the wide sweep of the horns of $O$. poli.

Small dark sheep, with horns of an open spiral, extend along the Selkirks in British Columbia to the American border, while the sheep of the main Rockies in the same latitude are clearly of the type species and have an extremely close spiral.

South of the Stone sheep, ranging from British Columbia into Mexico, is the true Rocky Mountain big-horn, O. cervina, with three subspecies; first, a salmon-colored race in southern California, O. nelsoni; second, an outlying form in Old Mexico, $O$. mexicamus; and third, in the Bad Lands of the upper Missouri River, O. auduboni.

ROCKY MOUNTAIN GOAT.

The only remaining member of the Bovidae to be considered is the Rocky Mountain goat, Oreamnos, consisting of two species, $O$. montanus, extending from the northern Rockies of the United States into Alaska, where it is replaced near the western limit of its range by an allied species, O. kennedyi, the horns of which are lyrate and relatively wide spreading. The British Columbian mountain goat is a much larger and finer animal than the type species in the United States, and has recently been assigned a subspecific rank, as has the smaller form in the mountains of Idaho.

We would expect to find more species of this animal, as it is a very aberrant form of the mountain antelopes or Rupicaprinae, a subfamily of the Bovidae, of which the chamois is the best known member. While not in any sense goats, the members of this genus are to some extent intermediate between the true or bovine antelopes and the goats.

The genus most closely allied to Oreamnos is Nemorhaedus, the members of which inhabit the central Asiatic plateau, where they are known to sportsmen as the goral. An outlying form in Japan, $N$. crispus, is well known as the serow.

This strange and interesting inhabitant of the Rocky Mountains is assigned to a peculiar genus, sharing its characters with no Old World species, and, while its lineage cannot be traced further back on this continent than the Upper Pleistocene, still 
its closest Eurasian relatives are farther removed than are those of the other American genera of the Bovidae. In other words, the gulf between Oreamnos and the nearest Eurasian form is of generic instead of specific dimensions.

In discussing the antiquity of Oreamnos, it must be borne in mind that it may well be, and probably is, as recent an immigrant as the other three genera of the Bovidae. A closely allied species may have existed in Siberia until very recently. Once extinct, and with no known fossil remains, we should have no trace of its existence. In the case of the musk-ox, the Eurasian and Alaskan forms died out, but their fossil remains were found and demonstrated the former existence of the genus in those countries.

As to the fossil record of the Bovidae in general, no sheep, goats, antelope or true oxen have been found fossil in America. In fact goats, antelopes, and true oxen never existed on this continent, and no bovines of any sort appear until the Middle Pleistocene, so that all the American genera of the Bovidae are beyond dispute of Eurasian origin.

Comparing these four outlying groups with the wonderful development which the members of this family attain in the Old World, we cannot help regretting, either that the American representatives have not been here longer, and evolved more distinct and striking types, or else that nature had, in the first instance, been more lavish in the number of species which crossed the Behring Sea land bridge.

Considering the Family Bovidae as a whole, we find by far the greatest number of genera and species in the Ethiopian region, and there can be little doubt that further investigation of the fossil fauna of Africa will disclose the ancestors of the extraordinary bovine antelopes which flourish on that continent.

It is most probable that all the Bovidae achieved their development in Africa in Oligocene and Miocene times. They first appeared in Eurasia, in the early Pliocene, became abundant and spread rapidly throughout the continent, reaching North America at a much later period, the Middle Pleistocene. At an early date some members of this family pushed to the far north, and becoming adapted to boreal conditions, produced types like the musk-ox. Others accepted a mountain habitat, and developed the goats, the sheep, and the mountain antelopes, the latter exemplified by the American Oreamnos. 
THE DEER.

In contrast to this probable African origin of the Bovidae, there is little doubt that the Cervidae, or deer family, achieved its development in Eurasia, with an important outlying group on this continent, which, springing from some early Eurasian ancestor developed into the American deer, Odocoileus.

There are in America five genera of this family. The first two, the moose, Alces, and the caribou, Rangifer, are circumpolar in distribution. Being animals of large size and great endurance, they can and do make long migrations, the moose rarely and only when impelled by danger or failing food supply, and the caribou at regular intervals. It is consequently not surprising to find a close resemblance between the Old and New World species of each genus.

Both the moose and caribou may have developed in some as yet unknown subarctic land. In fact these two genera seem to afford the only evidence from the fauna of North America in support of the theory of the boreal continent. Of the two, the caribou shows, in its structure, more adaptation to Arctic conditions.

Of the American moose only two species are known, one of limited distribution in southern Alaska, A. gigas, and the other, $A$. americamus, ranging from the limit of tree growth in western and northern Alaska to Nova Scotia on the Atlantic coast, and just entering the United States at several points along its northern boundary. It is a larger and finer animal than its Eurasian relative. This, too, holds true of the caribou.

We have in the American Pleistocene deposits a mooselike form known as Cervalces, with complex antlers which are highly suggestive of those of the giant Alaskan moose. This animal was closely related and possibly ancestral to the moose, in which case the moose may have developed in the northern part of the continent and crossed into Eurasia. More probably it represents another, and somewhat aberrant species of moose, coming in at the same time from northern Siberia or other boreal lands.

In the genus Rangifer we have a greater variety of types, and the species fall naturally into two groups: barren ground caribou and woodland caribou.

The first has five species: $R$. granti, of the Alaskan Peninsula on the west; $R$. stonei, of the Kenai Peninsula and adjoining mainland (the handsomest of barren ground caribou); the typical $R$. 
arcticus, of the Barren Grounds; $R$. pearyi, of Ellesmereland, and $R$. groenlandicus, of Greenland.

The second group, of woodland caribou, holds four species, all of which lie to the south of the barren ground species. In contrast to their northern cousins they are forest animals. In the Cassiar Mountains of British Columbia we have $R$. osborni, handsomest and largest of all caribou; $R$. montanus, of British Columbia, passing over the border into the United States; $R$. caribou, of Canada, east into Nova Scotia, and $R$. terraenovae, in Newfoundland.

These nine species are all fairly well separated, and are all, but especially the barren ground group, closely related to the Eurasian reindeer, of which as yet only three species have been described. Their varietal development on this continent indicates a long residence here, longer probably than that of the moose.

The next genus of the deer, Ceruus, has one outlying member in America, the wapiti. This genus first appears fossil in the Middle Pleistocene, and has only developed two local races of doubtful value, $C$. occidentalis, or the Olympic elk, and C. merriami, a small form from Arizona and the San Joaquin Valley in California. The wapiti once ranged to the Atlantic Ocean and as far northeast as the Adirondacks, and in the East may possibly have had local characters of subspecific value.

THE AMERICAN DEER.

Last of all the deer we come to a strongly marked genus, Odocoileus, which includes all North American deer not referred to above. There are in the United States and Canada at least four well-marked species, with seven or eight subspecies. In South and Central America there are at least twenty additional species, all belonging to Odocoileus, together with a closely related genus containing one small and aberrant form, Pudua.

All deer being of northern origin, these South American deer show signs of the deterioration which inevitably overtakes the members of the deer family when they enter the tropics.

Only three of the North American species need be referred to: first, the Virginia deer, O. virginianus, extending with its subspecies westward into the Rockies, and south into Florida and Texas, where it meets the closely related Cones' deer, O. conesi; second, the mule deer, O. hemionus, of the western plains and 
Rockies; and, third, the Columbia black-tailed deer of the Pacific coast, O. columbiamus, with its outlying subspecies in the North, the Sitka deer, O.c. sitkensis.

The genus Odocoileus departs widely from all the Old World types. Its closest allies, as far as foot structure is concerned, are Alces and Rangifer.

These American deer have been on this continent for a very long time, possibly as far back as the Miocene. They have spread throughout both North and South America, and have developed many well-defined species, both facts indicating a long period of radiation on this continent. The antlers of Odocoileus cannot be in any way correlated with those of any other genus of the deer family, least of all with those of Cervus.

All the members of the Cervidae sprang originally from the same stock, but this ancestral form was either hornless, or else had a simple spike, with, at most, a single branch, resembling the dag-antler of the yearling. This spike-horn ancestor is probably the correct explanation, as otherwise it is necessary to assume that the different members of the deer family acquired the extraordinary character of deciduous antlers independently, and to find a common ancestor we should have to go back to a hornless cervine, resembling the existing musk-deer or the Chinese water deer.

A Miocene group of ruminants found in North America, which has heretofore been considered as possibly ancestral both to Odocoileus and Antilocapra, proves, on close investigation, to be a new and separate family, or at least a clearly defined subfamily of the Bovidae. This group includes Cosoryx, Blastomeryx and Merycodus.

These merycodonts are practically antlered antelopes, being in foot structure, the high molar crowns, and in other characters, close to the bovine antelopes, and still closer to Antilocapra, and, were it not for the antlers, they might be considered ancestral to the latter. In this affinity to the prong-horns they suggest an American ancestry for that animal.

Paleomeryx, however, is a true deer, and is found both in the American Miocene and in the European Oligocene. It is a generalized cervine. The American forms had unbranched antlers, situated directly over the eye, apparently with permanent velvet, and without a burr, suggesting in these respects the giraffe. The European forms, however, although earlier, were much more specialized, and had both a burr and naked antlers, with a single prong. 
The existence of Paleomeryx in America proves that as early as the Miocene, deer existed here, which could readily have given rise to Odocoileus. This, taken together with the fact that there is no known Old World line which suggests Odocoileus, would indicate an American origin for the latter animal. Nevertheless Odocoileus is not found fossil earlier than the Middle Pleistocene, when both $O$. virginiamus and $O$. hemiomus appear at the same time with Cerous.

THE PRONG-HORN OR AMERICAN ANTELOPE.

Of the prong-horn, Antilocapra americana, and its aberrant characters, much could be written. It is not an antelope, not even in the sense that the mountain goat is an antelope, but stands absolutely alone, and represents one of Nature's efforts to evolve a horned animal. It certainly has developed all its peculiar characters on this continent, but has not yet been found fossil earlier than the Lower Pleistocene.

Although the family Antilocapridae, has but one genus and a single species, with a northern and southern form, yet its characters are so extraordinary that it is properly assigned to a rank of equal value with the Cervidae and the Bovidae.

The horns of the prong-horn differ greatly from those of the other hollow-horned ruminants, but not so much as do the horns of the latter from the antlers of the deer, but all the structural characters of the prong-horn, other than its exceptional horns, indicate an affinity with the bovine antelopes rather than with the deer.

First we have the peculiarity of the horns being placed directly over the eye, a character which the prong-horn seems to share with the American Miocene antlered antelopes or merycodonts. Next the horn structure itself is unique. It is not a bony process of the skull, like the antlers of the deer, but grows over a persistent horn-core. It is pronged, and, above all, is annually shed not long after the rutting season.

The horns of the Bovidae are a process of the skin, of the same material as hoofs, claws and nails. But the horns of the prongbuck are composed of agglutinated hair, paralleling in this respect the horn of the rhinoceros. However, hair is also an epidermal process, and the horns of the prong-buck are histologically closely related to those of the Bovidae.

The horns of other hollow-horned ruminants may be spiral, ly- 
rate, straight or curved, annulated or studded with bosses, but they can never be forked, and are never deciduous.

Which of these types of horn structure is the most ancient, that of the prong-horn, of the bovines, of the deer or of the giraffe, we do not know, but the present evidence from paleontology indicates that the lines of descent diverged before horns came into existence.

The giraffe and the kindred okapi, form another great group of horned animals, representing an entirely different scheme of structure, the horns being persistent and permanently covered with velvet. It has been suggested that this horn is a mere generalized structure, from which were evolved the antlers of the deer. This theory does not seem well supported by the facts, especially since a new species of giraffe has been recently discovered in Africa with an additional pair of horns, making five in all, the two extra horns being, like the third horn of the common species, quite rudimentary.

The okapi also has two rudimentary horn cores, indicated externally by mere tufts of hair. All these horns are rudimentary and cannot be correlated with the antlers of the deer.

A number of giraffine forms have been found in the Pliocene of Greece and India, and the Giraffidae appear to represent a separate line of descent from a hornless ancestor of African antecedents.

Nature made similar experiments in North America with the colossal Titanotheres, giving them paired horns on the extreme front of the skull, and with the Uintatheres, which had three pairs of horns. These efforts appear to have resulted in failures, since the groups no sooner obtained their full development than they rapidly became extinct.

On the other hand the rhinoceroses, with unpaired horns, set in the median line of the skull, have survived to the present day.

The horns of the giraffe and the bovines are present in both sexes, and are primarily weapons of defense, although the horns of male bovines are larger and stronger than those of the females. The branched and deciduous antlers of the deer and the pronghorn, on the other hand, are confined to the males, practically without exception, * and being functional only during the mating half of the year, are consequently secondary sexual characters.

* The female Caribou has small antlers. 


\section{DERIVATION OF NORTH AMERICAN MAMMALS.}

DIDELPHIDAE:

\section{MARSUPIALS.}

Didelphys, Opossum......... North American, of great antiquity.

\section{DASYPODIDAE:} EDENTATES.

Cabassous, Armadillo........................ South American.

\section{ERITHIZONTIDAE:}

Porcupines

RODENTS.

HAPLODONTIDAE: Sewellel,

GEOMYIDAE:

Pouched Rats,

Other Families. South American.

$B O V I D A E$ :

Ovibos, Musk-Ox,

Bison, Buffalo,

Ovis, Mountain Sheep,

Oreamnos, Mountain Goat,

CERVIDAE:

$\left.\begin{array}{l}\text { Alces, Moose, } \\ \text { Rangifer, Caribou, }\end{array}\right\}$ North American.

Cervus, Wapiti

Boreal or Eurasiatic.

......... Eurasiatic.

ANTILOCAPRIDAE:

Antilocapra, Prong-Horn................... North American.

DICOTYLIDAE:

Dicotyles, Peccary

North American.

URSIDAE:

CARNIVORES.

Ursus-Black Bear Group, $\}$ Eurasiatic, probably arriving in the $\left.\begin{array}{l}\text { Grizzly Bear Group, } \\ \text { Brown Bear Group, }\end{array}\right\} \begin{gathered}\text { order named. } \\ \text { or }\end{gathered}$

MUSTELIDAE:

$$
\text { Brown Bear Group, }
$$

$\left.\begin{array}{l}\text { Taxidea, Badger, } \\ \text { Mephitis, } \\ \text { Spilogale, }\end{array}\right\}$

Gulo, Wolverine,

Mustela, Marten,

Putorius, Mink,

Lutra, Otter,

Latax, Sea Otter,

PROCYONIDAE:

Bassariscus, Cacomistle, )

Procyon, Raccoon,

Nasua, Coati Mundi,

North American.

$C A N I D A E$ :

Urocyon, Grey Fox............... North American, doubtfully.

Canis, Wolf,

Vulpes, Fox,

Eurasiatic.

FELIDAE:

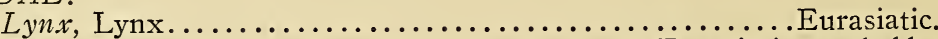

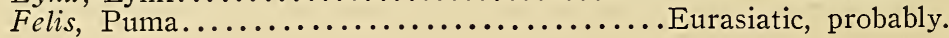


To sum up the contents of the preceding pages we find that we have:

First:-The Puerco radiation (in Europe also in part);

Second:--The Wasatch or Lower Eocene radiation (in Europe also in part).

In each of these two radiations we have three elements:

a. A fauna found both in America and in Europe;

b. An independent American fauna;

c. An independent Eurasiatic fauna.

Third:-A portion of the Second or Wasatch American fauna, by migration into Europe.

Fourth:-A portion of the Second or Lower Eocene Eurasiatic fauna, by migration into America.

In Miocene times there also appears an African fauna, a large portion of which enters Europe and Asia, sending into North and South America mastodons and into North America only, mammoths and modified Bovidae. In Pliocene times North America receives a South American fauna.

This completes our review of the important mammals of North America.

We find that the great majority of our large animals came recently from Eurasia, but all have been here long enough to develop characters of specific rank.

There is also a native element, which seems to have survived the devastation of the glaciers, including the prong-horn, the American deer, the peccaries, the raccoons and the opossums.

A small South American element, consisting chiefly of the armadillos and the porcupines, of considerable antiquity, can also be traced.

The element of recent arrivals is naturally strongest in the North, and in the Arctic itself we find certain species, like the white bear and the arctic fox, which are circumpolar in their distribution.

In the South the native element and the South American types become more and more prominent as we proceed through the United States and Mexico southward, until at last the face of nature changes, and we find ourselves in the tropics, amid the strange fauna of South America.

The writer desires to express his deep sense of appreciation of the courtesy and aid in the preparation of the above paper, of Prof. Henry Fairfield Osborn and of Dr. W. D. Matthew, both for their special knowl- 
edge of the subjects treated and for the material placed at his disposal by them in the American Museum of Natural History, and also to William T. Hornaday, Director of the New York Zoological Park.

Reference has been had to the following books:

The Geography of Mammals, by W. L. and P. L. Sclater.

Mammals Living and Extinct, by Flower and Lydekker.

Geographic History of Mammals, by Lydekker.

Mammalia, by F. E. Beddard.

Distribution of Animals, by Angelo Heilprin.

Island Life, by Alfred Russel Wallace.

A Synopsis of the Mammals of North America, by Daniel Giraud Elliot.

And especially: The Rise of the Mammalia in North America, The Law of Adaptive Radiation, in American Naturalist, 1902, The Faunal Relations of Europe and America, and Theory of the Successive Invasions of an African Fauna into Europe, New York Academy of Science, I900, by Henry Fairfield Osborn.

Classification of the Fresh Water Tertiary, The Merycodus, Field Notes, etc., in the Bulletins of the American Museum of Natural History, by W. D. Matthew.

Polar Climate in Time, by G. R. Wieland, in the American Journal of Science for December, I903.

Origin of the Primates, by J. L. Wortman, in the American Journal of Science for June, I903. 

p 
